\title{
Mixed Method Strategies to DevelopThe Acquisition of ESP Students' Skills of on Line Marketing
}

\author{
Bakhrul Khair Amal' ${ }^{1}$, Muhammad Natsir ${ }^{2}$, Supsiloani $^{3}$, Rita Suswati ${ }^{4}$ \\ ${ }^{1,3}$ Lecturer in Social Science Faculty of Universitas Negeri Medan, Medan - Indonesia \\ ${ }^{2,4}$ Faculty of Languages and Art, English Department of Universitas Negeri Medan, Medan - Indonesia \\ b4khul.4m4l@gmail.com, mnatsir@gmail.com, supsiloani71@gmail.com, rita.suswati@gmail.com
}

\begin{abstract}
English for Spesific purposes is one of the topicthat hold a great deal of advantages for students in Literature program. It aims to give a chance to the students to feel the working environment and see how it will be when they want to get involve into the bussiness. The variety jobs have been offered to youngsters but the most current opportunity is on line bussiness. It opens a wide range of chance for students to achieve. In order to do so, students should master some skills, not only pedagogic skills but also marketing skills. This research tries to answer the question of how to acquire ESP students' skillsof online marketing using mixed method, consist of qualitative, quantitative into a mixed method research approaches. The population is the senior students who are going to do field observations in several offices, consists of 30 students of english literature department program. The results show that; (1) Mixed Methods has a significat impact on the acquisition of ESP students' skills ofon line marketing, (2) online marketing is still a prosperous bussiness for the future. Further it is suggested to do more research on this area to enrich the knowledge of online bussiness as one of the new option of profession for students of english literature department program in FBS Universitas Negeri Medan (UNIMED).
\end{abstract}

Keywords : mixed method strategies, ESP, on line marketing

\section{Introduction}

Online bussiness has become one of the prosperious income for sellers theseday. Due to the globalization and the use of digital technology, applications in the cellphone not only used for the purpose of communication, chatting in particular but it is intended to be a market place for certain people who know how to develop their skills in on line marketing.

Further, (Alvarez and Fournier 2016; Kumar and Gupta 2016; Lamberton and Stephen 2016) branding is one of the most imortant thing in marketing to engage with the customers on digital world. Competision in digital platform becomes a way for student of english literature program of Universitas Negeri Medan (UNIMED) to learn. Nowadays to be part of the bussiness world, they are not only have to come to work places, controlled by work hours, and others. The learners can be the one who produce, sell, or even organize a company by involving in on line marketing. The great opportunity to achieve big income after graduating from University.

English for Spesific Purposes (ESP) is a topic which explore students' interest in the various of job offering. As the students of english literature of UNIMED, learners can choose to be other than teaching english, they have an open access in different working environment, namely secretary, translator, guide, police, and many more. The recent access for the student to gain is on line marketing. On line bussiness has covered all aspects in life. From communication to education. The implementation of learning more on each skill held through the internship program between english literature department program with each institution. 
The participants of this program are the senior students who are ready to face the working experience.

The senior students of english literature departement program who have been placed into different offices, not only learned the procedure in each offices but also have to record the term used at each offices to sell their product, both direct sell or on line marketing in particular.

Furthermore, they will have to design one simple product that people, especially youngsters will buy and discuss it in a group. This product is a leading way to a bigger idea to learn more of online marketing bussiness. They assisted by an expert from each offices. They can study, ask and develop their aquisition of online marketing not only the spesific terms used in each field buat also the tricks and trends in running the online marketing bussiness.

The scaffolding supported the students came from the experts from each fields and the lecturer who guide them in ESP class. The lecturers as the researchers engange directly into the proceess of getting the data analysis, from the preliminary data to the final product.

The theorical underpinnings of the importance of online marketing had been proposed by (Kannan and Li 2017; Lamberton and Stephen 2016), its been a challenge for academic researchers to study further on the viral subject these day, "online bussiness" in this digital era. Sure, we will find advantanges and disadvantages using this platforms to enhance students' development in practising their knowledge in society.

In marketing, there's been a little research done using mixed methods. Althought the rapid movement of this method have been held by many of the social sciences such as the National Institute of Health, the National Science Foundation, the National Research Council, and others have facilitating the promotion of the used of mixed method research techniques (Creswell et al., 2003), the focus of this research is the philosophical aspect that led the qualitative, quantitative, and mixed method research approaches (Bahl and Milne, 2006). In on line marketing, mixed method research isthe using of the qualitative and quantitative data into one research Johnson et al., 2007).

Further, Johnson et al., 2007, p. 123 defined mixed method as a study where a researcher or his colleques join the elements of qualitative and quantitative data analysis and technique mixed with other approaches like etnography for the depth analysis on an issue.

In this case the questionnare and interviews have been the instruments to get the students' perception on participating in on line marketing as a job offer than becoming a teacher. The researchers also "get into the skin" or involve into the bussiness itself by recorded the testimonies of the tenants who have been the sellers for many years, using an aide memoire to guide the participants' answer. Based on this data, we can assumed that students must notonly have hpedagogical skills to be a part of on line bussiness but also have to learn the marketing skills to be a better seller and engage with the customers.

The purpose of this study is to find the answers of these questuons: (1) Do the mixed methods has a significant impact to develop the acquisition of ESP students' skillsof on line marketing? (2) How is the prospect of online marketing in the future?

\section{Theorical Framework}

The theories applied as the basis of the research are the study by Commuri and Gentry (2005), they investigate the domestic issue which discuss on how a wive can earn 
more money that her husband. By using an exploratory design to know from where the wives get this kind of money. They did the interview of 20 couples a total of 64 times andthen tested it in an online survey among 126 married participants, using the mixed method. Further, the study by Arnold and Reynolds (2003), they also used exploratory design, to develop an instrument, into three phases.. It was included 98 depth interviews, coded thematically by a three-member coding team.

Creswell et al., 2003 stated that one of the purpose of explanatory design is to explain the relationships or study findings.

According to Tsou, Wang and $\mathrm{Li}, 2002$ learners can have one of these advantages by using technologies as a way to improve themselves in writing; (1) electronic devices can develop students creativity, analysis, and producing an idea a lot easier and efficient in a communication, (2) Exchange knowledge through email and sharing files improve their collaboration skills between friends and teachers, (3) It will build their motivation in writing, (4) technology had transformed into the effective tool to gain the information that used to get only from human (Ware and Warschauer as cited in Tsou, 2008).

The millenials have exposed with technology since their early age. The growth of techonology no longer become the entertaiment purposes only, teachers can get the benefit from technology to develop the acquisition of ESP students' skills of on line marketing, for instance.

Digital Marketing is the promotion of products or brands via one or more forms of electronic media. For example, advertising mediums that might be used as part of the digital marketing strategy of a business could include promotional efforts made via the Internet, social media, mobile phones and electronic billboards, as well as via digital and television and radio channels.Digital Marketing. businessdictionary.com. retrieved Dec 09, 2018 from businessdictionary.com.website:http://www.businessdictionary.com/definition/digitalmarketin g.html.

The recent trends of on line marketing had moved away from statictic data analysis into the field study. By using qualitative and quantitative data, mixed with etnography study, its expected to get the students' perception of on line marketing as a prosperous job opportunity in the future.

Welcoming the industrial revolution of 4. 0, The Indonesia Pesident, Joko Widodo, initiate and launch the program called " Making Indonesia 4.0", its a goverment commitment to embrace the coming of industrial revolution, in order to do so, the educational system should be reformed and repaired. Teachers not only design the materials and method but also have to complete themselves with technology. The word KKN (Corruption, Collution and Nepotism) had reformed into (Communication, Collaboration and Networking), this discussion held in a seminar under the title "The Future of Global Higher Education" at Batavia, Tower Jakarta, Saturday (4/9).CNN Indonesia.com. retrieved Dec 08, 2018 from CNN Indonesia.com website: https://www.cnnindonesia.com/gaya-hidup//metode-pendidikan.

From the data analysis of each field, its found each field has a different use of online marketing. The way they applied it as a source of bussiness also affected the outcomes of revenue from each offices. The students' perception on this matter also classified into two part. The one who thought that digital marketing will be a prosperous bussiness for the future, and the other had the opposite assumptions. The Interpretations of each students and experts will be explain more on the following topics: 


\section{Students' Perception}

The results of all findings (questionnare and interviews) will need more description to get into the skin what is actually students'thought, perception of online marketing as an optional job offer. The transcription of the participants interviews will be shown in the form of tables.

Table 1. The Important of Digital Mark

\begin{tabular}{|c|c|c|c|c|}
\hline \multirow{4}{*}{$\begin{array}{l}\text { As an English } \\
\text { literature students, why do } \\
\text { you need to study on line } \\
\text { marketing? }\end{array}$} & $\begin{array}{l}\text { Academic } \\
\text { purposes }\end{array}$ & 30 & 4 & $13 \%$ \\
\hline & Job offer & 30 & 18 & $60 \%$ \\
\hline & $\begin{array}{l}\text { Millenial } \\
\text { Era }\end{array}$ & 30 & 7 & $23 \%$ \\
\hline & No purpose & 30 & 1 & $3 \%$ \\
\hline \multirow{4}{*}{$\begin{array}{l}\text { What kinds of digital } \\
\text { marketing that you are } \\
\text { familiar with? }\end{array}$} & tokopedia & 30 & 10 & $33 \%$ \\
\hline & lazada & 30 & 8 & $27 \%$ \\
\hline & bukalapak & 30 & 10 & $33 \%$ \\
\hline & Others & 30 & & $\overline{6.7 \%}$ \\
\hline \multirow{3}{*}{$\begin{array}{l}\text { Would you consider } \\
\text { to be a part of digital } \\
\text { marketing expertise? }\end{array}$} & Yes & 30 & 22 & $\overline{73 \%}$ \\
\hline & No & $\underline{30}$ & 7 & $23 \%$ \\
\hline & Hesitate & 30 & 1 & $\overline{3 \%}$ \\
\hline
\end{tabular}

\section{Methodology}

This study uses mixed method approaches that combine qualitative, quantitative and ethnograpic approaches. The method used is descriptive- exploratory method to identify the students and experts' perceptions on the prosperous only bussiness in the future The participants were 30 (S1-S30) english literature program students who placed in 5 different field (News office, Tourism office, Goverment office, Private office and Bank) and 5 (E1-E5) supervisors (experts) from each field to guide the students in finishing their reports. Each of these offices used digital marketing as one of their platforms engaging with the customers.

Instruments of data analysis are questionnaire, observation sheet and interview questions' list, using open and axial coding as Strauss \& Corbin, 1998 proposed. The interviews were tape-recorded. The data were collected by semi-structured in-depth interviews (Creswell, 1998) with An aide-memoireto guide the participants in answering the questions.

\section{Analysis}

From the data, its found that students thought of the Fneed of online marketing is one opportunity to offer a job, almost $60 \%$ of the students still perceive that by studying digital bussiness will also open a new chance to get a better career.

Further investigation made to find out the type of digital marketing the students most 
open and purchase, it seems lazada and tokopedia are still the most familiar tenants among students with the same $33 \%$ of percentage .

Finally, when they were being asked to be a part of marketing expertise, 22 students agree to become a digital marketer.

Table 2 will show what kind of application students used as a media to do online marketing. The application only classify into 4 types (Ig, FB, WA and Line). It was made from the previous investigation related to the most common applications used among students (Suswati, 2018). The following data shown as below:

Table 2. The most frequently used as media of digital marketing

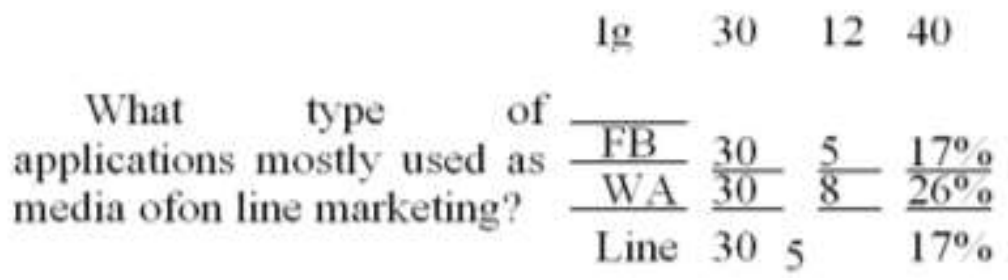

It was found that the students have familiar with digital marketing among them, especially in Instagram. Almost $40 \%$ of the studentns choose Ig as a media to do on line marketing. They purchase many things though social media frequently.

They are only 5 experts to supervise students' work on their internship for almost 6 months. They had different statement related to students'passion in learning digital marketing. 4 of the experts consider that each students have the same levels of acquitision in understanding the digital bussiness terms and they were at the same proficiency in joining the digital marketing. Only one supervisor considered that the students only used media social or digital platform to join a community without be able to get revenue of it, for intance like selling stuff. The different perception towards each experts described as follow;

1. "They have a good motivation and passion in studying digital marketing, alhtough they still often on using digital platform as a way to entertain themselves, but they see this internship as a breakthrough to get a better job" (E1-Banker).

As a banker, the E1 had dealt with on line marketing for ages, its really satisfying him when the students finally decided to see digital marketing as a bright future.

2. "At first, they seems clueless of what they are going to deal with, but in the end they really focus on choosing online marketing as their carreer" (E2- Government Officer).

E2 supervised these students for almost 6 months to see their process in decidiing online marketing as their career.

3. "Some of these students motivated to be a teachers and applied the digital bussiness as the examples for their students"(E3-Tourism Officer).

Being a teacher is a nobel choice of life, by implementing digital platform is a good example of participating in industial revolution 4.0.

4. "They have lack of vision of what heading in the future, the amusement is still their priority for now" (E4-Private Officer),

When they didn't have a purpose in life, its quite difficult for them to see their future. 
5. "The passionate had shown to me that they will have a prosperous job in digital world" (E5-News Officer).

\section{Result}

The investigation of this study have some result;

1) Mixed Methods has a significat impact on the acquisition of ESP students' skills of on line marketing,

2) Online marketing is still a prosperous bussiness for the future.

Mixed method applied in this study consist of qualitative, quantitative and ethnography approaches. The transcriptions of the data divided into tables and interpretation of the experts. The tables indicates that most students used digital platform all the times, some as a way to join a community, others more smart in using it as a way to get revenue. $60 \%$ of the students assume that digital marketing will open a new opportunity for them and $73 \%$ of them agree that they are going tobe on line marketing expertise.

While some students acted as a purchaser, little of them have already being a seller and engage with the customers through social media. The most frequent used as a media of digital marketing is Ig, almost $40 \%$ of the students check new product in Instagram. They have familiar with tenants like bukalapak and tokopedia with the same percentage of $33 \%$.

The 4 experts consider these english literature students will focus on digital marketing and have prosperous carreer, while the last one didn't see the seriousity of his supervise students in learning digital marketing.

\section{Conclusions}

To conclude the investigation of mixed method strategies to develop the acquisition of ESP Students' Skills of On Line Marketing, it is assume that digital marketing, especially online marketing is a great deal of opportunity for students in the future.

Digital marketing is also one of the solution in anticipating the industial revolution 4.0 and the term KKN (Corruption, Collution and Nepotism turn into Communication, Collaboration and Networking).

The access of digital platforms should move from the amusement purposes into the revenue purpose.

\section{References}

Arnold, M.J. and Reynolds, K.E. (2003), "Hedonic shopping motivations", Journal of Retailing, Vol. 79 No. 2, pp. 77-95. Avlonitis,

Anniek W. Eigenraam \& Jiska Eelen\& Arjen van Lin\& Peeter W.J. Verlegh A Consumerbased Taxonomy of Digital Customer Engagement Practices is Department of Marketing, Vrije Universiteit Amsterdam, De Boelelaan 1105, 1081 HVAmsterdam.

Alvarez, Claudio and Susan Fournier (2016), "Consumers' Relationships with Brands," Current Opinion in Psychology, 10, 129-35. 
Creswell, J.W. and Plano Clark, V.L. (2007), Designing and Conducting Mixed Methods Research, Sage, Thousand Oaks, CA. Creswell, J.W., Plano Clark, V.L., Gutmann, M.L. and Hanson, W.E. (2003), "Advanced mixed methods research designs", in Tashakkori, A. and Teddlie, C.B. (Eds), Handbook ofMixed Methods in Social and Behavioral Research, Sage, Thousand Oaks, CA, pp. 209-40.

Harrison, Robert L. Mixed methods designs in marketing research Western Michigan University, Kalamazoo, Michigan, USA, and Timothy M. Reilly University of Nebraska-Lincoln, Lincoln, Nebraska, USA

Johnson, R.B., Onwuegbuzie, A.J. and Turner, L.A. (2007), "Toward a definition of mixed methodsmethods research", Journal of Mixed Methods Research, Vol. 1 No. 2, pp. 112-33

Kannan, P.K. and Hongshuang Alice Li (2017), "Digital Marketing: A Framework, Review and Research Agenda," International Journal of Research in Marketing, 34, 1, 22-45.

Tsou, W. (2008). The effect of a web-based writing program in collegeEnglish writing classes. IEEE Computer Society Washington, DC, USA.Retrieved on October 25,2017 from: http://portal.acm.org/citation.cfm?id=1381740.

Tsou, W; Wang, W., \& Li, H. (2002). How computers facilitate English foreign language learners acquire English words. Computers \& Education, 39(4), 415- 428.

CNN Indonesia.com. retrieved Dec 08, 2018 from CNN Indonesia.com website:

https://www.cnnindonesia.com/gaya-hidup//metode- pendidikan 